\title{
Corporate Governance of Banks and Financial Institutions: Economic Theory, Supervisory Practice, Evidence and Policy
}

\author{
Klaus J. Hopt ${ }^{1}$ \\ Published online: 16 March 2021 \\ (C) The Author(s) 2021
}

\begin{abstract}
Banks are special, and so is the corporate governance of banks and other financial institutions. Empirical evidence, mostly gathered after the financial crisis, confirms this. Banks practicing good corporate governance in the traditional, shareholder-oriented style fared less well than banks having less shareholder-prone boards and less shareholder influence. The special governance of banks and other financial institutions is firmly embedded in bank supervisory law and regulation. Most recently there has been intense discussion on the purpose of (non-bank) corporations. For banks stakeholder governance and, more particularly, creditor or debtholder governance is more important than shareholder governance. The implications of this for research and reform are still uncertain. A key problem is the composition and qualification of the board. The legislative task is to enhance independent as well as qualified control. The proposal of giving creditors and even supervisors a special seat in the board is not convincing. Other important special issues of bank governance are for example the duties and liabilities of bank directors in particular as far as risk and compliance are concerned, but also the remuneration paid to bank directors and senior managers or key function holders. Claw-back provisions, either imposed by law or introduced by banks themselves, exist already in certain countries and are beneficial. Much depends on enforcement, an understudied topic.
\end{abstract}

Keywords Corporate governance $\cdot$ Economics of bank governance $\cdot$ Debtholder governance $\cdot$ Purpose of the (bank) corporation · Financial institutions · Bank regulation $\cdot$ Bank supervision

\footnotetext{
This article is in memory of Brigitte Haar, friend, esteemed colleague and academic pupil. She was such a great scholar and enthusiastic academic teacher and, for those who had the privilege to know her more closely, a wonderful person and a true companion. This article is the expanded and footnoted version of a lecture made at the Frankfurt Symposium in memory of Professor Brigitte Haar on 25 September 2019, which was based on earlier articles in The Journal of Corporate Law Studies (2013) 13:21 and, in the German language, in ZGR 2017, 438 and WM 2019, 1771.
}

Klaus J. Hopt

hopt@mpipriv.de

1 Max Planck Institute for Comparative and International Private Law, Hamburg, Germany 


\section{Introduction: General and Sector-specific Corporate Governance}

\subsection{Corporate Governance of Private Listed Corporations}

Corporate governance has become a key topic in international practice and economic and legal theory. ${ }^{1}$ The definitions of corporate governance vary. Corporate governance is certainly not just corporate law. ${ }^{2}$ The short-form definition used by the Cadbury Commission in 1992 is to the point and internationally agreed upon: Corporate governance refers to 'the system by which companies are directed and controlled'. ${ }^{3}$ Direction and control can come from inside or outside. Internal corporate governance refers to government and control by the organs of the corporations, the board in the one-tier system or the management and supervisory boards in the two-tier system. Accordingly, it is hardly astonishing that much of the corporate governance literature deals with the board. ${ }^{4}$ External corporate governance can be understood as the disciplinary effects exercised in particular by the takeover market on the directors but also, to a certain degree, effects exercised by the markets for directors, products and services. ${ }^{5}$ External corporate governance is weaker for financial institutions than for corporations in general since there is no well-developed market for corporate control as regards financial institutions. Until recently, takeovers did not have a significant corporate control effect for banks, ${ }^{6}$ at least not in Europe. Yet under the pressure of globalization, shrinking returns, digitalization and in particular fierce competition from non-bank institutions, this may change soon.

\subsection{Other Varieties of Corporate Governance for Other Enterprises and Sectors (Non-listed, State-owned, Non-profit, Insolvency, Banking and Insurance)}

Corporate governance was first developed as a concept and field of research for private listed corporations. This was due to the self-regulatory efforts of stock exchanges and other private institutions that either had certain requirements for admission or set up recommendations on good corporate governance, usually with corporate governance codes, sometimes with the help of the comply or explain-principle set up by legislators. The idea of developing corporate governance standards spread quickly to other sectors, such as to non-listed companies (among them in

\footnotetext{
${ }^{1}$ For a comparative examination of corporate governance, research and international regulation, Hopt (2011). Most recently in German language Hopt and Leyens (2020).

2 Gilson (2016).

3 Report of the Committee on the Financial Aspects of Corporate Governance, London, December 1992 (Cadbury Report).

4 See the excellent survey by Adams et al. (2010); Davies et al. (2013); Binder (2018).

5 In more detail Hopt (2011), p 8.

6 Adams and Mehran (2003), p 126; Laeven (2013), p 71; de Haan and Vlahu (2016), pp 232 et seq. On individual cases (ABN AMRO/Banca Antonveneta 2005, RBS/ABN AMRO 2007, BNP/Société Générale 1999) see Tsagas (2015), p 285, opposing shareholder primacy and favoring more state control, but without unleashing the threat of protectionism. On control transactions Davies et al. (2017).
} 
particular family companies, ${ }^{7}$ state-owned enterprises (SOEs) with public corporate governance codes, ${ }^{8}$ non-profit organizations and foundations ${ }^{9}$ ), insolvent companies and companies in serious financial crisis ${ }^{10}$; the notion of corporate governance was also extended to banks, insurance companies and other financial institutions such as rating agencies. ${ }^{11}$ While corporate governance principles for listed corporations have been and are still a major source of inspirations for corporate governance in these other sectors, there is very little cross-fertilization as regards the corporate governance efforts in these other sectors. Therefore, this article basically compares the governance of financial institutions-with banks taken as an example-with general corporate governance, and it will make the point that the corporate governance of banks is different in many respects.

\section{3 'Banks are Special': Particular Economic Features of Banks and Other Financial Institutions}

The Basel Committee on Banking Supervision, the world's leading authority on banking regulation and banking supervision, begins its 2015 Guidelines on Corporate Governance Principles for Banks with the words: 'Effective corporate governance is critical to the proper functioning of the banking sector and the economy as a whole. ${ }^{12}$ The corporate governance of banks and other financial institutions ${ }^{13}$ has gained much attention after the financial crisis. ${ }^{14}$ From 270 economic and legal submissions from 2012 to 2016 in the ECGI Working Paper Series of the European Corporate Governance Institute (ECGI), roughly half address corporate governance questions, and more than a quarter of these look at the regulation and corporate governance of banks (in the broad sense). ${ }^{15}$ The financial crisis certainly contributed to this, yet whether the financial crisis can really be attributed mainly to financial institutions' shortcomings in corporate governance, as some authors assert, is doubtful. ${ }^{16}$

\footnotetext{
7 Aronoff and Ward (2011); Garnacho Cabanillas (2019).

${ }^{8}$ OECD, OECD Guidelines on Corporate Governance of State-Owned Enterprises, 2015 edn., Paris.

9 Hopt and von Hippel (2010).

10 Becht (2010); Adams (2012); Ferreira et al. (2016); Berger et al. (2016); Schenker (2017).

11 Miglionico (2019).

12 Basel Committee on Banking Supervision, Guidelines, Corporate governance principles for banks, Bank for International Settlements (BIZ), Basel, July 2015, p 3. For Sect. 1.3 of this article, see the earlier German-language version in ZGR 2017, 438, 441-444.

13 On the definition of the Basel Committee based on agency theory and with inclusion of other stakeholders as shareholders, Basel Committee (n. 12), p 1 Glossary. The term is used in an economic sense and encompasses insurance entities and other financial intermediaries. 'Banks' are being used here as representing the whole of financial institutions, but the emphasis lies on banks in the narrow sense of the word.

14 In detail, Hopt (2013); Chiu (2015); Armour et al. (2016), ch. 17: Bank Governance; Barth and Levine (2016); Levine (2016); Mallin (2016). Most recently Hopt et al. (2020). Cf. the long list of bank failures during the financial crisis in Becht et al. (2011), pp 439 et seq.

15 Merkt and Klausmann (2016), pp 254 et seq.

16 Hopt (2012), paras. 11.16 et seq.; Berger et al. (2016); Binder (2015b), pp 697 et seq.; Kotz and Schmidt (2016), p 440; Siems and Alvarez-Macotela (2017), p 327; also Cheffins (2009). Contra Mülbert and Wilhelm (2015), paras. 6.74 et seq. The international institutions that have attempted to justify their own initiatives on this topic have in the meantime become more cautious, e.g. European Bank-
} 
In theory, practice and supervision, it is a truism that banks are special as compared to non-banking institutions. This is the very basis for the targeted regulation and supervision of banking as a regulated industry. The unique aspects of banks include the very low capitalization of banks as compared to non-banking entities (particularly when short and long financial maturity periods are matched); the complexity and non-transparency of banks' business activities and structures; the fundamental need for trust and the associated danger of bank runs; and in particular the macroeconomic function of banks as manifested in their central importance for the economy, which in turn gives rise to their being subject to far-reaching legislation and state regulation. ${ }^{17}$ Their uniqueness is reflected in frequently recurring banking crises and the structural flaw whereby banks are seen as 'too big to fail' and 'too interconnected to fail', such that state rescue is needed whenever a bail-in is either not an option or proves ineffective. ${ }^{18}$ One cannot dispute that these unique characteristics are of course of particular importance for systemically important banks (SIFIs). But they are not limited to such entities. Instead these attributes are of more general relevance, even if they are naturally more consequential and visible in the case of SIFIs. ${ }^{19}$

It is hardly astonishing that these special characteristics of banks demand, in turn, a special variety of corporate governance. Yet what is surprising is that particular attention to this has traditionally been absent and that economic research as to the special governance of banks has commenced relatively late. One of the earliest contributions to the field dates from the $1980 \mathrm{~s} .{ }^{20}$ Several factors seem to have contributed to this delay in research. Empirical studies, found mostly in US academic literature, usually focused on the principal-agent dilemma and were oriented on the conflict between directors and shareholders, this corresponding to the US shareholder structure (mostly dispersed shareholdings and relatively few major blockholdings). ${ }^{21}$ Consequently, given this focus and in accord with the available data, the natural object of inquiry tended to be publicly-traded companies. Even where banks were the topic of inquiry, earlier studies focused on principal-agent theory as framed

\footnotetext{
Footnote 16 (continued)

ing Authority (EBA), Consultation Paper, Draft Guidelines on internal governance (2016), p 6: 'not a direct trigger for the financial crisis'. It is, however, not disputed that corporate governance deficits were 'closely associated' with the crisis and resulted in misplaced incentives. See Summers (2000), p 1.

17 Laeven (2013), pp 66 et seq.; Kotz and Schmidt (2016), pp 427 et seq. On the economics, law and policy of regulation see Avgouleas (2012); Barr et al. (2018). Most recently on bank regulation Binder et al. (2020).

18 See Wymeersch et al. (2012); Ferran et al. (2012), and, in the same work, especially as to the USA, Coffee (2012), pp 301 et seq.

19 See e.g. Admati and Hellwig (2013).

20 As the earliest proponents, see Corrigan (1982) and Fama (1985); special issue: Corporate Governance: What Do We Know, and What is Different about Banks?, Economic Policy Review (The Federal Reserve Bank of New York, FRBNY) (2003) 9:1, and therein Adams and Mehran (2003). Cf. also for corporate governance in general, Tirole (2001), p 4: 'The traditional shareholder value approach is too narrow a view of an economic analysis of corporate governance For an extensive survey of literature on bank governance and performance see Fernandes et al. (2018).

21 Kotz and Schmidt (2016), pp 430 et seq., who, by contrast, stress the economic theory of the nexuses of incomplete contracts and various theories on capitalism, the latter in connection with Hall and Soskice (2001).
} 
by studies in non-banking contexts. By contrast, empirical studies looking specifically at corporate governance in the banking context—and demonstrating the unique characteristics which ensue-are only a more recent development. In the context of this present paper, only a few important findings can be discussed. ${ }^{22}$

Fahlenbrach and Stulz ${ }^{23}$ report that worse results were achieved by bank CEO's whose actions were primarily motivated by shareholder interests. Similar findings were reached by Beltratti and $\mathrm{Stulz}^{24}$ as regards bank boards. Banks with shareholder-friendly boards had significantly poorer results. According to other studies, the composition and characteristics of bank boards had significant effects, ${ }^{25}$ and boards with relatively higher shareholder representation undertook more and greater risks. ${ }^{26}$ Apparently bank boards charted a course more aligned with the preferences of shareholders, ${ }^{27}$ who-if sufficiently diversified in their holdings-embrace risk more readily than, for instance, a bank's creditors. ${ }^{28}$ Beltratti und Stulz thus doubt the hypothesis that bad corporate governance was a significant cause of the financial crisis. ${ }^{29}$ Banks with independent boards were run more poorly. ${ }^{30}$ Banks that were controlled by shareholders saw higher profits before the crisis as compared to banks that were controlled by directors. ${ }^{31}$ Enterprises in which institutional investors held stocks correspondingly fared worse. ${ }^{32}$ In general, studies showed that the shareholder structure of a bank correlated strongly to the bank's insolvency, particularly where low-level management was significantly involved in the decision-making process. ${ }^{33}$

These and further empirical studies suggest that it is erroneous to conclude that traditional-even if empirically established-approaches to the corporate governance of corporations can be seamlessly applied to the corporate governance of

\footnotetext{
${ }^{22}$ In further detail Becht et al. (2011); Hopt (2013), pp 239-244; Laeven (2013); Hagendorff (2015), p 139; for a comprehensive survey of the empirical studies, de Haan and Vlahu (2016), and Fernandes et al. (2018): separate CEO and chairman, independence of directors, size, experience, diversity et al.; briefly also Ferrarini (2017). Recently, see e.g. Hamdani (2017) and Tröger (2017). On the submissions in ECGI Merkt and Klausmann (2016). But see van der Elst (2015), advancing a limiting view; nevertheless, at the end of p 32 he in fact concedes that bank governance poses a special case.

${ }^{23}$ Fahlenbrach and Stulz (2011). Anginer et al. (2018) find higher stand-alone and systemic risk in the banking sector when corporate governance was shareholder-friendly.

24 Beltratti and Stulz (2012); also Ferreira et al. (2016), with further references. Also agreeing in this regard, van der Elst (2015), p 32, but with the remark that the composition of boards is dissimilar not only as between banks and non-banks, but also as between countries.

25 Spong and Sullivan (2010).

26 Pathan (2009).

27 See Agarwal et al. (2009).

28 Laeven and Levine (2009); Ferreira et al. (2016).

29 On this disputed question, see n. 16 above.

${ }^{30}$ Erkens et al. (2012); Pathan (2009); Pathan and Faff (2013). Cf. Ferreira et al. (2012). For further references to empirical studies finding neutral, negative and (exceptionally) positive relationships, see de Haan and Vlahu (2016), pp 251-254; Fernandes et al. (2018), p 243, but also p 252.

31 Gropp and Köhler (2010). See also Saghi-Zedek and Tarazi (2015), with mixed results.

32 Erkens et al. (2012).

33 Berger et al. (2016). On the various empirical studies demonstrating partly contradictory findings regarding shareholdership, CEO and director shareholdership, and government ownership, de Haan and Vlahu (2016), pp 256 et seq.; see also Hagendorff (2015), pp 151 et seq. For a contrasting view, van der Elst (2015).
} 
banks; in fact, exactly the opposite may be true. This is the case, for example, as regards director independence, which according to recent studies can carry negative effects also in the case of non-financial corporations, ${ }^{34}$ whereas expertise and experience are of much greater value, at least when obvious conflicts of interest are avoided. Still, it bears emphasis that sound judgment is called for when evaluating empirical findings. Often, findings warranting a differentiated assessment are held up against one another despite their embodying nuanced differences that may reflect a dissimilar time horizon in the studies, an inadequate account of the interdependence of certain factors and, above all, country- and path-dependent differences resulting from legal regulation and cultural circumstances. ${ }^{35}$

\section{Governance of Banks and Financial Institutions in Supervisory Law and Practice}

\subsection{The Basel Committee on Banking Supervision: The Guidelines, Corporate Governance Principles for Banks, 2015}

The Basel Committee has issued the authoritative Guidelines on Corporate governance principles for banks, released in a revised version in July $2015 .^{36}$ The Guidelines, while underlining the jurisdictional differences and the necessity of proportionality and differences in governance approaches, set out 13 major principles in respect of banks' corporate governance. They concern (1) The overall responsibilities of boards, (2) Board qualification and composition, (3) The structure and practices of boards, (4) Senior management, (5) Governance and group structures, (6) Risk management functions, (7) Risk identification, monitoring and control, (8) Risk communication, (9) Compliance, (10) Internal audits, (11) Compensation, (12) Disclosure and transparency and (13) The role of supervisors. This list sounds familiar to someone who is accustomed to dealing with corporate law and corporate governance, though already at first glance Principle 4 on senior management and Principle 13 on the role of supervisors are special for bank governance. As in corporate governance of non-banking entities, the board is at the center of the attention. But the demands on its composition, qualification, responsibilities and practices are much higher than for non-bank corporations. The risks a bank runs are of course very special. Accordingly the requirements concerning the bank board's governing and controlling functions are spelt out in considerable detail and are much more demanding. So are the disclosure and transparency requirements. It is interesting to see that a special principle is devoted to the governance of group structures, groups

\footnotetext{
34 Cavaco et al. (2017).

35 Hall and Soskice (2001). This is also acknowledged by de Haan and Vlahu (2016), p 266. Making reference to the particularities of the German three-column banking system, Kotz and Schmidt (2016), pp 428 et seq.; this also after the dismantling of 'Deutschland AG' (Germany Inc.) and traditional Rhineland capitalism, ibid. pp 434, 437 et seq. As to the latter, Ringe (2015).

${ }^{36}$ Basel Committee (n. 12). The first Basel Committee document 'Enhancing Corporate Governance for Banking Organisations' dates already from 1999.
} 
of companies being subject to special legal treatment in only some countries (like Germany), while in others they are not recognized as a special area in corporate law and governance. ${ }^{37}$ The Guidelines do not have the character of legally binding norms, but they spell out in detail what rules banks should observe. ${ }^{38}$

\subsection{Principles and Guidelines of Other Supervisory Institutions (European Banking Authority 2016/17, the Financial Stability Board 2017 and Similar National Supervisory Agencies In and Outside of the European Union)}

The crisis resulted in many other international institutions adopting recommendations, supervisory measures and regulations in the area of corporate governance as regards the banking industry. Though scarcely addressed by academic authors, many of these instruments and schemes are now in their second or even third generation, e.g. the Guidelines on internal governance of the European Banking Authority (EBA) of 2017, ${ }^{39}$ the Joint ESMA and EBA Guidelines from 2017, ${ }^{40}$ the report of the Financial Stability Board (April 2017), ${ }^{41}$ the Guidelines of the European Central Bank of $2018^{42}$-and those of similar national supervisory agencies, for example the Swiss FINMA (September 2016) ${ }^{43}$ or the German Federal Financial Supervisory Agency (BaFin 2016/2017) ${ }^{44}$-and for the

\footnotetext{
37 Hopt (2018).

38 A detailed description and analysis of the Guidelines can be found in Emmenegger (2020a).

39 EBA, Final Report, Guidelines on internal governance under Directive 2013/36/EU, EBA/ GL/2017/11, 26 September 2017. See also EBA Guidelines on the Assessment of the Suitability of Members of the Management Body and Key Function Holders of 22.9.2012 and the consultation on 'fit and proper' by the EBA und the European Central Bank (ECB) 2016.

40 ESMA/EBA, Final Report, Joint ESMA and EBA Guidelines on the assessment of the suitability of members of the management body and key function holders under Directive 2013/36/EU and Directive 2014/65/EU, EBA/GL/2017/12, 26 September 2017.

41 Financial Stability Board (FSB), Thematic Review on Corporate Governance, Peer Review Report, 28 April 2017, as found at p 3: The primary objective is the application of the G20/OECD Principles of Corporate Governance 2015 'to publicly listed regulated financial institutions e.g. banks, insurers, asset managers and financial holding companies)'. See OECD, The G20/OECD Principles of Corporate Governance, OECD Report to G20 Finance Ministers and Central Bank Governors, Paris, September 2015. As to them, Siems and Alvarez-Macotela (2017).

42 European Central Bank (ECB), Guide to fit and proper assessments, May 2018 (updated in line with the joint ESMA and EBA Guidelines on suitability).

43 Eidgenössische Finanzmarktaufsicht FINMA (Swiss Financial Market Supervisory Authority), Bern, Circular 2017/1, Corporate governance-banks: Corporate governance, risk management and internal controls at banks, 22.9.2016.

44 Bundesanstalt für Finanzdienstleistungsaufsicht (BaFin), Merkblatt zu den Geschäftsleitern gemäß KWG, ZAG und KAGB, 4.1.1016 (last amended 12.11.2018); BaFin, Guidance Notice on Members of Administrative and Supervisory Bodies pursuant to the German Banking Act (KreditwesengesetzKWG) and the German Capital Investment Code (Kapitalanlagegesetzbuch-KAGB), 4.1.2016 (last amended 31.1.2017); BaFin, Circular 09/2017 (BA)—Minimum Requirements for Risk Management (MaRisk)—MaRisk, 27.10.2017.
} 
insurance companies the International Association of Insurance Supervisors (November 2015). ${ }^{45}$

\subsection{CRD IV, National Bank Supervisory Laws, Legal and Policy Analyses}

The concepts and recommendations of the Basel Committee made their way not only into the principles and guidelines of other international and national supervisory institutions, but also into the bank supervisory law of the Member States of the European Union via the Capital Requirements Directive (CRD IV). ${ }^{46}$ Further, via the Solvency II Directive, ${ }^{47}$ they entered similarly into the Member States' supervisory law of insurance companies.

Accordingly, as to the academic literature, much of it is just a doctrinal legal presentation and a commentary-like treatment of the actual supervisory law in the various Member States. A significant amount of the literature deals with the European law in the CRD IV ${ }^{48}$ — as well as in Solvency II and regarding its implementation for insurance supervision-looking particularly at supervisory boards/boards of directors/CEOs, most of it purely de lege lata, ${ }^{49}$ but at times based more on functional legal policy considerations. It is true that there are some authors who question the whole approach of the Basel III regulation, but this is due to fundamentally different views towards regulation. ${ }^{50}$ In any case, there is criticism of over-regulation as voiced by the industry, and a large number of academic authors rightly join in the latter's complaints. ${ }^{51}$ The provisions drafted by legislators, supervisory agencies and international bodies ${ }^{52}$ are indeed increasingly detailed; while these provisions are, legally speaking, only persuasive in nature, they are de facto more or less binding. Yet despite often being adopted in the wake of corporate scandals ${ }^{53}$ and while frequently tending to overshoot the target, regulation remains both unavoidable and indispensable.

The interplay between stock corporation law, bank supervisory law and insurance supervisory law in corporate governance is considered more rarely. ${ }^{54}$ Yet there is a basic agreement on the necessity of taking note of the similarity of supervisory problems in the separate fields as well as of trying to harmonize rules whenever the problems are functionally similar, while maintaining different rules and regulations

\footnotetext{
${ }^{45}$ International Association of Insurance Supervisors (IAIS), Insurance Core Principles, updated November 2015. See also OECD Guidelines on Insurer Governance, 2005, revised 2011.

46 Capital Requirements Directive (CRD IV) of 26 June 2013 [2013] OJ L 176/338.

47 Solvency II Directive (Solvency II) of 25 November 2009 [2009] OJ L 335/1.

48 On CRD IV cf. Mülbert and Wilhelm (2020); Finesi (2015), pp 64 et seq.

49 German Banking Act (Gesetz über das Kreditwesen-KWG), Insurance Supervision Act (Versicherungsaufsichtsgesetz-VAG). For detailed references to the German literature on this Act see Hopt (2017), pp 444 et seq.

50 See e.g. Romano (2014); Enriques and Zetzsche (2014).

51 See e.g. Ferrarini (2017), pp 19, 24: favoring a supervisory rather than a regulatory approach, corresponding to the difference between principle-based und rule-based regulation.

52 Above Sect. 2.2.

53 Hail et al. (2017); Hopt (2011), pp 16 et seq.

54 Van den Hurk and Siri (2019).
} 
when the risks and features are different. Cross-sectoral regulation is needed. ${ }^{55}$ Some have rightly observed that a European bank corporation law is gradually developing in its own right, and these authors ask what effect the European banking union will have on the governance of credit institutions. ${ }^{56}$ Corporate governance of banks may even pave the way to a self-contained law covering financial intermediaries and their corporate governance.

\section{Shareholder, Stakeholder or Creditor Governance: The Controversies Regarding the Purpose of Corporations and Banks}

\subsection{Shareholder or Stakeholder Governance: The German Experience and the American and European Discussion on the Purpose of Corporations}

The purpose of corporations is an old and controversial topic. The classic approach is the one that prevails in the United States: the purpose of a corporation is to make profit for the shareholders. On the other side of the spectrum stands Germany. There, the board is responsible to promote the interests of all stakeholders, i.e. the shareholders, labor and the public good. While the shareholder-oriented approach had gained some attention also in Germany before the financial crisis, the traditional stakeholder concept is still generally agreed upon. The labor interest is even further consolidated by the mandatory labor co-determination at parity in the supervisory board. Other European states, such as the United Kingdom, follow a middle way with the so-called enlightened shareholder approach, a shareholder orientation that also looks at the interests of other stakeholders in view of preserving a longterm profitability of the firm (Europe) ${ }^{57}$ But in the United Kingdom this concept is increasingly criticized as too vague and hardly effective. It is of note that most recently even in the United States there has been a tendency towards having more regard for the full spectrum of stakeholders' interest, as promulgated by the business roundtable statement in $2019 .{ }^{58}$ Yet whether this non-binding declaration of many American business leaders will really amount to a change in practice remains to be seen. In any case, in times and terms of financial rescue and insolvency proceedings,

\footnotetext{
55 Binder (2019); Busch and Palm-Steyerberg (2019).

56 Binder (2015a), in particular general prudential requirements and remuneration, pp 479 et seq.; Binder (2016).

57 Compare the modifications in Kraakman et al. (3rd edn, 2017), para. 1.5, pp 22-24 with idem (2nd edn., 2009), para. 1.5, pp 28-29; the language in the later edition was agreed to after extensive discussions: '(S)hareholder value is the proper object of corporate law' because shareholders are the 'residual claimants' and because shareholder value is a less ambiguous yardstick for assessing the performance of directors, what naturally should not be pursuing profit maximization at any price. Summarizing the German discussion Hüffer and Koch (2020), § 76, Rn 28 et seq.; accordingly, the board is obliged to weigh the diverging interests pursuant to the principle of practical concordance.

58 Business Roundtable, Statement on the Purpose of the Corporation, August 19, 2019, available at https://opportunity.businessroundtable.org/ourcommittment/.
} 
it has been recognized that risk together with governance ('ownership') is transferred from the owners to the creditors. ${ }^{59}$

\subsection{Towards Creditor or Debtholder Governance for Banks}

As regards bank corporations and financial institutions, the case is clearly different. Empirical findings, the experience of the financial crisis, and economic and legal conclusions have produced a change in perspective that amounts to a theory of creditor (i.e. debtholders and depositors) governance. ${ }^{60}$ The Basel Committee on Banking Supervision's benchmark guidelines, the Corporate Governance Principles for Banks from July 2015, state at the very beginning: 'The primary objective of corporate governance should be safeguarding stakeholders' interest in conformity with public interest on a sustainable basis. Among stakeholders, particularly with respect to retail banks, shareholders' interest would be secondary to depositors' interest. ${ }^{61}$ This corresponds to the standing supervisory practice of other national and international banking agencies too.

This position is a clear rejection of the shareholder primacy view, but it differs also from the only slightly tempered view held in Europe, since banks are expected to consider creditor interest not only when this is in the long-term interest of the corporation. ${ }^{62}$ Creditor governance is not just a question of the purpose of bank corporations, instead having consequences in many other areas regarding the corporate governance of banks. In particular this view reduces also the relative importance of controlling shareholders, institutional investors and shareholder control in general, as is presently the center of attention in the corporate governance of (non-bank) corporations. $^{63}$

\subsection{Implications for Research and Reform: Self- or Co-Regulation, Mandatory Transparency, State Regulation}

Along with the theoretical assessment of corporate governance of banks and financial institutions as creditor governance, there comes the task of examining the various problems associated with corporate governance-which, as regards (non-financial) corporations, have been comprehensively considered in international practice

\footnotetext{
59 Cf. Kraakman et al. (2017), pp 127 et seq.: Distressed firms and 114: The vicinity of insolvency; Schenker (2017).

${ }^{60}$ In more detail Hopt (2013), pp 243 et seq.; ESMT Berlin (2019). From an economic perspective, Macey and O'Hara (2003); Kotz and Schmidt (2016), p 440: '(S)hareholder governance needs to be complemented by [...] depositor or creditor governance.' Debt governance alone is, however, insufficient; rather, it is necessary to have state regulation and particularly demands regarding capital (see Admati and Hellwig 2013) and enforcement, below Sect. 4.3.

61 Basel Committee (n. 12), p 3, Introduction No. 2.

62 In further detail, Hopt (2011), pp 6 et seq.

63 To be sure, all this must not necessarily be extended beyond the banking and financial sectors; Ferrarini (2017), pp 19 et seq.: justified only from a regulatory viewpoint and not to be accepted in corporate law.
} 
and academic literature ${ }^{64}$ - and to determine what this implies for the corporate governance of banks and financial institutions. This is a comprehensive task, for which here only a few benchmarks can be given and for which some examples can be given in Sect. 4, below. This should be reflected in a research agenda ${ }^{65}$ that is jointly devised and pursued by economists and jurists and perhaps representatives from other disciplines. ${ }^{66}$ Before examining what the new look means for a number of regulatory core issues of banking, its relevance for two more general regulatory approaches should briefly be mentioned: self-regulation and regulation by transparency.

As to self-regulation of banks, ${ }^{67}$ experience in the financial sector is rather mixed. ${ }^{68}$ In Germany voluntary codes for insider trading did not work; in the end European legislators had to step in. The same was true when the German Takeover Commission adopted a voluntary takeover code. A considerable number of German enterprises did not comply with it, and their free-riding forced the German legislature to intervene with the German Takeover Act. The German Central Bank went through a similar experience when the European transborder bank group regulation was not yet in sight and the Bank tried to regulate with mere 'moral suasion'. But there is no rule without exception. In the Netherlands, in addition to European and Dutch banking regulations, the corporate governance of banks is further enhanced by a voluntary bankers' code of conduct which has been set up by the banking community itself (Dutch Banking Code) ${ }^{69}$ Even a bankers' oath similar to the Hippocratic Oath is foreseen, an oath that is reported to have been taken by around 90,000 bank employees. Some voices had been supporting a similar experiment in Germany, ${ }^{70}$ but the German banking association shied away for two reasons. First, they argued that banking legislation is already tough enough, maybe too tough, and, second, they feared that the legislature might turn parts of the code into binding law. Yet it seems obvious that mere voluntary self-regulation is not enough. Honesty in the banking industry - as a product of the existing business culture-is alarmingly low, as an empirical study by Fehr and others, published in Nature, has established. ${ }^{71}$ There is a case at least for co-regulation between the banking industry and state supervision. ${ }^{72}$

Transparency and disclosure are traditional instruments serving shareholder and creditor protection. The two aims are usually linked, particularly since investors can be both shareholders and creditors. Transparency plays an especially significant role

\footnotetext{
${ }^{64}$ See e.g. Fleckner and Hopt (2013). Offering the German perspective Hommelhoff, Hopt and von Werder (2009).

65 From an economic perspective, see e.g. Hagendorff (2015), p 155 at the end: '(T)hese unique features of banks call for a more profound rethink of the corporate governance of banks, one that centers around debtholders rather than equity holders'.

66 See Busch et al. (2019a, b).

67 As to the German Corporate Goverance Code see Hopt (2019).

68 Hopt (1998) as a member of the then German Takeover Commission.

69 The Dutch Banking Code, 2nd version 2015; Laaper and Busch (2019).

70 Hopt (2016).

71 Cohn et al. (2014).

72 As to the theory of co-regulation or cooperative regulation, Leyens (2018), pp 210 et seq.
} 
for banks and financial institutions. The Basel Committee holds in its Principle 12 on Disclosure and Transparency: 'The governance of the bank should be adequately transparent to its shareholders, depositors, other relevant stakeholders and market participants. ${ }^{, 73}$ Yet here transparency has-unlike with companies-an additional function, namely keeping supervisory bodies informed, as it minimizes their need to intervene or facilitates a more targeted intervention. ${ }^{74}$ Particularly with banking groups, complex and opaque structures give rise to risk; in the wake of the banking crises such structures have recurrently led to requirements of greater transparency. ${ }^{75}$ More disclosure can of course conflict with the need for secrecy, and public transparency may not produce exclusively positive consequences. ${ }^{76}$ Nevertheless, where not excessive and where account is had of the differences between the addressees (inter alia, regarding their size, complexity, structure, economic significance and risk structure), transparency and disclosure are in fact more market-friendly instruments than mandatory legislation and state supervision. ${ }^{77}$

\section{Regulatory Core Issues for the Corporate Governance of Banks and Financial Institutions}

\subsection{Composition and Qualification of the (One-tier or Two-Tier) Board: Enhancing Independent Control}

Enhancing independent control by targeting the composition of bank boards ${ }^{78}$ in the interest of creditors would be the most structured intervention. This could be done either directly by having creditors sitting on the board or indirectly by having somebody else entrusted with taking care of their interests. ${ }^{79}$

\footnotetext{
73 Basel Committee (n. 12), pp 36 et seq.

74 See e.g. Basel Committee (n. 12), Principle 12 Disclosure and transparency, pp 36 et seq.; EBA, Final Report, Guidelines on internal governance under Directive 2013/36/EU, Title VII Transparency, pp 54 et seq.

75 See also Basel Committee (n. 12), pp 23 et seq.: complex or opaque structures; Hopt (2012), para. 11.19 , pp 345 et seq., together with other weak spots that have become apparent in the wake of the financial crisis.

${ }^{76}$ For a comprehensive study see Leuz and Wysocki (2016).

77 On transparency as the primary regulatory instrument of the EU Commission in recent times, see Hopt (2015), pp 202 et seq.

78 Empirical studies on bank boards are mostly Anglo-Saxon in origin and consider the one-tier board. For Germany, however, see e.g. Johansen et al. (2017). For empirical findings on the relevance of the size of the board see Adams and Mehran (2012); Berger, Kick and Schaeck (2014); Fernandes et al. (2018), pp 244-245; de Haan and Vlahu (2016), pp 234 et seq. (suggesting no significance); and on diversity Hagendorff (2015), pp 149 et seq., but uncertain as to the extent something particular should be adopted for banks.

79 E.g. Hagendorff (2015), p 155 on creditor representatives, potentially corresponding to the existing level of leverage; Becht (2010), pp 1625 et seq., with considerations on the representation of creditors or creditor interests by deposit insurance entities such as the Federal Deposit Insurance Corporation (FDIC) in the USA.
} 
Since creditors are less risk-prone than shareholders, it might indeed make sense to have them sitting in bank boards. ${ }^{80}$ Actually, this is what several economists have proposed following the financial crisis, among them Martin Hellwig, the wellknown bank economist from the Bonn Max Planck Institute. The proposal recalls earlier considerations for seating a public interest representative on the board, ${ }^{81}$ an idea that was never adopted because the public interest is hard to grasp and such a representative may easily be captured by politics. It is true that creditor interest is more specific and that bondholders might indeed have an interest in moderating the risk-taking by a bank. Yet in view of the German co-determined boards, giving creditors one or more seats in the board could only further split up the board at the expense of the shareholder side and endanger the difficult balance between capital and labor within the board, possibly with limits under the German Constitution.

Another idea would be to entrust the labor side or one of the labor representatives with specifically taking care also of the creditors' interests. Yet experiences with co-determination in companies suggest that workers do not view themselves as representing the interests of other creditors, neither internally within the company nor externally as unions; rather, the workforce recognizes and heeds its own specific interests.

Then why not give the bank supervisors a regular seat in the bank boards $?^{82}$ This idea has indeed been brought forward in the discussion. At first glance it looks good. After all, it is the supervisors' official responsibility to protect the interest of debtholders, and they could make sure that the risks assumed by the bank are raised and considered in the board. But three arguments stand against this. First, the bank supervisors already now have the right to take part in the sessions and deliberations of the board if they consider it necessary for their supervisory work. Second, regular board membership for the supervisors would create a serious conflict of interest since they would have to oversee as supervisors what they co-decided as board members. Third, the reform would have consequences for the liability of supervisors, which up to now the legislature has strictly avoided.

Another route for influencing the composition of bank boards would be making more specific use of independent directors. The conventional wisdom is that independent directors are indispensable for overseeing the executive directors in the interest of the shareholders - a belief that, as we have seen, had its origins in the USA and Great Britain, namely countries with typically dispersed shareholding-though the cure-all quality ascribed to independent directors has significantly abated in recent years. ${ }^{83}$ Yet for banks empirical research has suggested that the

\footnotetext{
${ }^{80}$ E.g. Hagendorff (2015), p 155 on creditor representatives, potentially corresponding to the existing level of leverage; Becht (2010), pp 1625 et seq. with considerations on representation of creditors or creditor interests by deposit insurance entities such as the Federal Deposit Insurance Corporation (FDIC) in the USA.

${ }^{81}$ E.g. Bericht der Sachverständigenkommission zur Auswertung der bisherigen Erfahrungen bei der Mitbestimmung (Mitbestimmungskommission), BT-Drucks. VI/334, 1970, pp 107 et seq.

${ }^{82}$ For a more detailed analysis see Davies and Hopt (2019), paras. 6.43 et seq.

83 Davies et al. (2013), pp 28 et seq., 34 et seq.; see also Davies and Hopt (2013), pp 301-375; Ferrarini and Filippelli (2014).
} 
independence of management or supervisory bank board members is - setting aside conflicts of interests - of far less importance than expert knowledge and experience. ${ }^{84}$ An apparent exception relates to audit and risk committees, for which independence plays a major role. ${ }^{85}$ The data show that for most large international banks board independence does not constrain bank risk-taking. ${ }^{86}$ Qualifications and expertise stand clearly in the foreground of the official recommendations and the supervisory practice too. ${ }^{87}$ Accordingly, even for independent directors, bank supervisors attach more importance to independent judgment rather than to the possession of an independent background. ${ }^{88}$

The composition of bank boards is special when it comes to banks that are totally or partially owned by the state or other public authorities (SOEs). ${ }^{89}$ In Germany there is a particular experience with the state banks (Landesbanken) dating back to the financial crisis. While the Basel Committee on Banking Supervision has offered only cursory comments in this regard, ${ }^{90}$ the empirical findings are unequivocal. Specifically, significant influence exercised by public authorities is accompanied with a negative impact on the quality of corporate governance in banks and financial institutions as well as on their performance. ${ }^{91}$ This holds especially true when organ members are appointed less for their expertise than for political affiliation or for similar other reasons. Thus an empirical study looking at the profile of twenty-nine of the largest banks during the financial crisis showed that public banks, primarily Landesbanken, experienced three times greater losses than banks having private shareholders between the first quarter of 2007 and the third quarter of 2008. The supplementary study focusing on the biographies of 593 supervisory board members from these public banks revealed that their experience in management and finance was systematically less than the level seen in private banks. The correlation between losses, on the one hand, and reduced qualifications and experience, on the other, was highly significant statistically and suggested causation. ${ }^{92}$ More generally

\footnotetext{
${ }_{84}$ Erkens, Hung and Matos (2012) and further studies by de Haan and Vlahu (2016), pp 251 et seq. See also Adams and Mehran (2012); Nguyen et al. (2016), p 31.

85 Yeh et al. (2011), p 437.

86 Vallascas et al. (2017).

87 E.g. Basel Committee (n. 12), Principle 2, although reference as regards composition is made to 'a sufficient number of independent directors', it is clear that the directors cannot have any conflicts of interest; $\mathrm{p} 3$. $§ 25 \mathrm{~d}$ of the German Banking Act as well demands that management and members of supervisory organs have, in the first place, the necessary substantive expertise. But see, for instance, FINMA (n. 43), p 5: requiring one-third, with exceptions possible. See also Finesi (2015), p 45.

${ }^{88}$ FSB (n. 41), s. 4.5, pp 38 et seq.

89 See the OECD Guidelines on Corporate Governance of State-Owned Enterprises (2015) (n. 8); on the role of public corporate governance codes, Hopt (2021). On SOEs Adolff et al. (2019).

90 Basel Committee (n. 12), Introduction No. 22, p 7, namely only: 'The principles of sound corporate governance should also be applied to state-owned or state-supported banks, including when such support is temporary' (with reference to the OECD Guidelines).

91 De Haan and Vlahu (2016), para. 4.2 Government Ownership, pp 263 et seq. Generally on the effect of corporate governance on the performance of banks, cf. Davies and Hopt (2019); on US investment banks, Mamatzakis and Bermpei (2015).

92 Hau and Thum (2010). See also the resounding criticism of Wohlmannstetter (2011), pp 31, 47 et seq., 61 et seq.
} 
the relationship between the state and firms, specifically banks, can lead to harmful dependencies and interactions. In particular there is the danger of regulatory capture. ${ }^{93}$ While this danger may be less acute for bank supervisors who after the financial crises are under close observation of the financial press, the general public and legislators, it may still become a problem. As the state is expected to regulate and supervise banks more closely, an inquiry into the economic effects of this symbiotic relationship between the state and the banks becomes even more essential. ${ }^{94}$

\subsection{Duties and Liabilities and the Pay of Bank Directors, Senior Managers and Key Function Holders; Bank Groups}

As compared to corporations in general, ${ }^{95}$ the duties imposed on the organs of banks are stricter, much more detailed and of a mandatory nature. ${ }^{96}$ This is true particularly since the financial crisis. European and Member State supervisory practice as to the bank boards is far-reaching and demanding. Of primary concern are, rightly, risk management and compliance. ${ }^{97}$ But regulation and supervision also cover organizational and operational issues (as addressed by various committees-particularly a risk committee ${ }^{98}$ ). More recently, the compensation of bank directors has become a hot issue. Quite apart from societal concerns, the regulatory aim here is to avoid misplaced incentives. ${ }^{99}$ There is, as well, an appreciation of the unique

\footnotetext{
93 Baxter (2011); Carpenter and Moss (2013).

94 Also addressing the topic, Langenbucher (2012), p 665, finding the issue still mostly unresearched.

95 Cf. Hopt and Roth (2015); Hopt and Roth (2019).

96 While basically justified, in particular for SIFIs, it holds true, though to a lesser degree, also for other banks; these duties have reached a degree which may not be fully justified empirically and which have been criticized as overregulation. Comprehensively, Binder (2015b); Chiu (2016); Langenbucher (2020). For an international view, see Paolini (2015). Correctly opposing a general duty of bank directors to consider systemic risks when making decisions (public governance duty), Hamdani (2017), finding there to be an overly open-ended standard; however, Hamdani considers treating systemic risks as being similar to self-dealing, thus requiring full transparency and agreement of the entire board, but potentially only agreement of the independent directors. For a general treatment of systemic risk in the financial sector Arner et al. (2019). See also the introductory footnotes.

97 The Basel Committee (n. 12) devotes no less than four of its thirteen Principles to the topic. The FINMA (n. 43) bundles requirements regarding corporate governance, risk management and internal controls for banks. Extensively on internal control frameworks having a risk management function, EBA (n. 39), pp 38 et seq., 45 et seq. See Ellul and Yerramilli (2013); Mülbert and Wilhelm (2014); Saguato (2019); van Setten (2019); Stulz (2016). On board composition and risk taking Berger et al. (2014). On compliance Helleringer and Skinner (2019).

98 E.g. $\$ 25$ d ss. 7 and 8 of the German Banking Act, see on this point, Boos et al. (2016), § 25d KWG, comments 83 et seq., 96 et seq.

99 Rules and literature abound. Notable international contributions include the Financial Stability Forum (FSF), Principles for Sound Compensation Practices, 2009, and Principles for Sound Compensation Practices: Implementation Standards, 2009; Ferrarini (2019). For empirical findings see de Haan and Vlahu (2016), pp 264 et seq., p 266; Hagendorff (2015), pp 143 et seq. On the compensation requirements in the revised Shareholder Directive and its transformation into German law (ARAG II) Spindler (2020). Viewing uniform rules on compensation in the banking sector critically, with reference to the disparities among countries, van der Elst (2015).
} 
dangers of banking groups, ${ }^{100}$ such as interconnectedness, loss of confidence and bank runs. For this reason the current mass of bank group regulation is considerably more exacting than that which is applicable to corporate groups generally. ${ }^{101}$

In view of all this, proposals such as stricter personal director liability ${ }^{102}$ are not really convincing; other better-aimed, organizational and systemic measures may be more effective. But another, more promising proposal has just been made for directors, not specifically bank directors. ${ }^{103}$ Under the proposed scheme directors would be liable for compliance failures, but limited in quantum to a proportionate clawback of stock-based pay. This system could be introduced by bank legislators or by shareholder proposals or judicial innovation. The authors call this a 'compliance clawback'. Under German law this is not a novelty, and it can be found already in practice. The recent German act on strengthening shareholder rights in accord with the European Shareholder Rights Directive II $^{104}$ provides for mandatory disclosure on whether and how the corporation has actually made use of the possibility to claw back variable components of the remuneration of directors. ${ }^{105}$

For corporations, the focus of corporate governance and stock corporation law is clearly on the board, be it the one-tier board or the management and the supervisory boards. Second or third-tier management levels are left exclusively to labor and labor law. This compartmentalization of legislation and research may work for corporations in general, but certainly not for banks and other financial institutions. The financial crisis has shown that many of the abuses at the forefront of the bank business have been perpetrated by dealers and advisors acting below the board level. Solely requiring the board to organize and monitor bank personnel is not enough to prevent excessive risk-taking. Bank managers who are actually undertaking risky business must be addressed directly. In particular, risk-enhancing incentives such as certain bonus structures must be avoided. This is why under bank governance and banking regulation, senior management and key function holders ${ }^{106}$ as such are covered by recommendations and governance requirements. It is true that this may be in conflict with labor law that, at least in Europe, to a large degree shields employees from personal liability. But either bank governance rules should prevail or a legal solution for this conflict must be found.

\footnotetext{
${ }^{100}$ E.g. Basel Committee (n. 12), Principle 5, pp 22 et seq.: Governance of group structures; FINMA (n. 43), Nos. 98, 99; Macey and O'Hara (2016), pp 90 et seq. as to bank holding companies.

${ }^{101}$ For a skeptical view of this regulation, see e.g. Binder (2015b), pp 697 et seq.: questionable 'realworld analysis', p 707: counter-productive; Ferrarini (2017), p 2: favoring cautious deregulation, pp 24 et seq. Cf. on corporate governance of groups, Hopt (2018); on corporate governance of financial groups, Yasui (2016).

102 Armour and Gordon (2013); Kokkinis (2018); Schwarcz et al. (2019).

103 Armour et al. (2020).

104 Directive (EU) 2017/828 of 17 May 2017 amending Directive 2007/36/EC as regards the encouragement of long-term shareholder engagement [2018] OJ L 132/1.

105 Section 162, subsection 1, phrase 2, number 4 of the German Act (ARUG II). On the regulation of bankers' pay Bebchuk and Spamann (2010).

106 Basel Committee (n. 12), Principle 4: Senior management; EBA (n. 39), p 54. See also Finesi (2015), pp 61 et seq.
} 


\subsection{Enforcement: Civil, Penal and Administrative Sanctions, Private Enforcement}

In the general discussion on corporate governance, the questions of enforcement and control are assigned a central importance. ${ }^{107}$ This corresponds to an increased orientation in literature and research not merely on substantive company and banking law questions, but also to problems related to procedural law and insolvency law insofar as corporations are concerned. In the area of banking law, one even speaks of a shift from banking contract law to bank supervisory law and bank regulation. Yet based on the above-mentioned empirical findings, this simply does not correspond to more enforcement by shareholders ${ }^{108}$ (specifically by large shareholders, institutional investors and hedge funds - all of which are currently at the center of the corporate governance discussion-and notwithstanding the current attempt to subject institutional investors to mandatory rules of conduct or non-binding codes of conduct). ${ }^{109}$ But also a conclusion to impose legal obligations on the creditors-in the place of investors-would be inadequate since that would mean merely shifting the problem from one group of stakeholders onto another. Small creditors like small investors have a rational disinterest, particularly when they are protected by deposit guarantees. Bond creditors as well have only a limited potential and interest in influencing and monitoring the corporate governance of issuers. ${ }^{110}$ The internationally customary covenants found in the terms and conditions of a loan are not much help in this regard either. ${ }^{111}$ Large investors such as banks hold a variety of security agreements and thus, outside of the situation of insolvency, generally have little incentive to intervene. The previously existing network of financial relationships (Deutschland-AG) and the principal banking system (Hausbankensystem) have largely been dismantled. ${ }^{112}$ What remains is control by state supervision: specifically bank and insurance supervisory control, that - functioning much like a trustee for debtholders and depositors-(i) must ensure the effectiveness and enforceability of corporate governance rules, (ii) must possess the necessary competence and

\footnotetext{
$\overline{107}$ Cf. Hopt (2011), pp 19 et seq.: internal corporate governance, pp 52 et seq.: labor, pp 61 et seq.: external corporate governance. On securities law enforcement, Kraakman et al. (2017), para. 9.2, pp 258 et seq. Prudential regulation and corporate governance should complement each other, Laeven (2013), pp 80 et seq. For Sect. 4.3 see the earlier German-language version in ZGR 2017, 438, 456-458. On internal and external corporate governance of banks Ringe (2020).

${ }^{108}$ Similarly Armour et al. (2016), pp 388 et seq. Liability actions by shareholders under corporate law are relatively rare; more commonly they arise under the rubric of capital markets law. As an international example, one can consider the shareholder lawsuit against the Royal Bank of Scotland alleging deception of the shareholders; the suit ended in a settlement.

${ }^{109}$ Having a model character in this regard is the Financial Reporting Council, Stewardship Code 2020, in force as of 1 January 2020, available at https://www.frc.org.uk/investors/uk-stewardship-code. It is also important to note that institutional investors on the capital market can invest in bonds alongside stocks. On the more recent impact of index funds for corporate governance Bebchuk and Hirst (2019).

${ }^{110}$ Hopt (2013), p 243 as regards debtholders.

${ }^{111}$ Extensively as to bond terms, Oulds (2017), particularly as to covenants, paras. 3.44 et seq.; on change-of-control, para. 3.82; on cross-default, para. 3.92.

112 Ringe (2015).
} 
be capable of imposing sanctions, ${ }^{113}$ and (iii) must have specialized certified bank auditors at its disposal. ${ }^{114}$ To this we can add the energetic application of the fitand-proper standard and disqualification. ${ }^{115}$ But by the same token, it is vital that supervisory regulations do not smother the board; rather, under the mantra of coregulation, a certain discretion should be afforded the board so as to allow for independent, internal enforcement. ${ }^{116}$

In addition to this, there might also be a role for banks' own codes of conductwhether internal or applicable for the entire sector-as is shown, for instance, by the Dutch Banking Code ${ }^{117}$ and as is highly recommended by institutions such as the Basel Committee, the EBA and the FSB. ${ }^{118}$ Here, a clear deficit can be identified in Germany. ${ }^{119}$ Internationally, there are successful experiences with the implementation of soft law by the National Contact Points (NCP) under the OECD proposals on corporate social responsibility that could offer orientation to the banking sector too. In the end, however, it inevitably boils down to the ethical standards prevailing among companies and business leaders, who must set the tone from the top. This applies generally to the corporate governance of companies, and it is especially true in respect of banks and financial institutions. ${ }^{120}$

\section{Conclusions}

1. Banks are special, and so is the corporate governance of banks and other financial institutions as compared with the general corporate governance of non-banks. Empirical evidence, mostly gathered after the financial crisis, confirms this. Banks practicing good corporate governance in the traditional, shareholder-ori-

\footnotetext{
113 FSB (n. 41), s. 2.3, pp 15 et seq.: Effectiveness and enforceability of corporate governance frameworks. For the USA, for instance, enforcement rights of the FIDIC, Atherton v. FIDIC, 519 US 213 (1997). As to the limited role of criminal law, Hopt (2014); Armour et al. (2016), p 390, mentioning the Financial Services (Banking Reform) Act (2013), s. 36: criminal offence in cases of reckless misconduct causing the firm to fail; for Switzerland, Emmenegger (2014); Nobel (2020); for developments in the US, see Macey and O'Hara (2016), p 101; Emmenegger (2020b).

114 Practically all of the institutions named (supra Sect. 2) stress the role of supervisory entities, particularly for corporate governance; on the role of independent, competent and qualified auditors, see e.g. FSB (n. 41), pp 5, 24 et seq. On auditors as financial intermediaries falling between internal and external corporate governance, Leyens (2018). On applying good corporate governance to financial regulators Jabotinsky and Siems (2017). Cf. most recently Binder (2020).

115 Busch and Palm-Steyerberg (2019). On the role of the supervisor see Mülbert and Wilhelm (2020), pp 244-247.

116 Ferrarini (2017), pp 24-25. Cf. Hodges (2015). Mülbert and Wilhelm (2020), pp 275-278 plead for enhancing proportionality.

117 Laaper and Busch (2019).

118 Basel Committee (n. 12), p 5: 'Management should develop a written code of ethics or a code of conduct.' EBA (n. 39), pp 31, 55; FSB (n. 41), pp 5 et seq. with recommendation 6, p 30.

119 Hopt (2016), p 75; in brief, idem, Audit Committee Quarterly III/2015, p 20.

${ }^{120}$ On the role of corporate culture, see e.g. Financial Reporting Council, Corporate Culture and the Role of Boards: Report of Observations, July 2016; Zhu and Ferrarini (2019).
} 
ented style fared less well than banks having less shareholder-prone boards and less shareholder influence.

2. The special governance of banks and other financial institutions is firmly embedded in bank supervisory law and regulation. Starting with the recommendations of the Basel Committee on Banking Supervision, many other supervisory institutions have followed the lead with their own principles and guidelines for good governance of banks. In the European Union, this has led to legislation on bank governance under the so-called CRD IV (Capital Requirements Directive), which has been transformed into the law of the Member States. The legal literature dealing with this is mostly doctrinal and concerned with the national bank supervisory law. But there are also more functional legal as well as economic contributions, these addressing primarily, but not exclusively, systemically important financial institutions. The latter are under a special regime that needs separate treatment.

3. Most recently there has been intense discussion on the purpose of (non-bank) corporations. Shareholder governance and stakeholder governance have been and still are the two different prevailing regimes in the United States and in Europe, particularly in Germany. Yet for banks this difference has given way to stakeholder and, more particularly, creditor or debtholder governance, certainly in bank supervision and regulation.

4. Yet the implications of this for research and reform are still uncertain and controversial. For banks, self-regulation, if at all, must give way to co-regulation or cooperative regulation between the banks and the state. Mandatory transparency is indispensable. For banks this transparency has the additional function of informing the regulators and supervisors in order to facilitate their task of creditor and debtholder protection and more generally the protection of the economy. Particular qualification and independence problems arise for state-owned banks.

5. The regulatory core issues for the corporate governance of banks are manifold. A key problem is the composition and qualification of the (one tier or two tier) board. The legislative task is to enhance independent as well as qualified control. Yet the proposal of giving creditors a special seat in the board disregards the reality of labor codetermination. Giving bank supervisors a permanent seat in the board would create serious conflicts of interest since they would have to supervise themselves.

6. There are many other important special issues of bank governance, for example the duties and liabilities of bank directors in particular as far as risk and compliance are concerned, but also the remuneration paid to bank directors and senior managers or key function holders. Claw-back provisions, either imposed by law or introduced by banks themselves, exist already in certain countries and are beneficial.

7. Much depends on enforcement, an understudied topic. A mix of civil, penal and administrative sanctions, possibly coupled with private enforcement, may have advantages.

8. The corporate governance of banks is an ongoing task for supervisors, regulators and legislators, but also one for the banks themselves. In banking, ethics is indispensable, and the tone from the top matters. 
9. For all of these issues, more economic, legal and interdisciplinary research on corporate governance in banks and financial institutions is needed, and it could also help pave the way forward. ${ }^{121}$

Funding Open Access funding enabled and organized by Projekt DEAL.

Open Access This article is licensed under a Creative Commons Attribution 4.0 International License, which permits use, sharing, adaptation, distribution and reproduction in any medium or format, as long as you give appropriate credit to the original author(s) and the source, provide a link to the Creative Commons licence, and indicate if changes were made. The images or other third party material in this article are included in the article's Creative Commons licence, unless indicated otherwise in a credit line to the material. If material is not included in the article's Creative Commons licence and your intended use is not permitted by statutory regulation or exceeds the permitted use, you will need to obtain permission directly from the copyright holder. To view a copy of this licence, visit http://creativecommons.org/licen ses/by/4.0/.

\section{References}

Adams RB (2012) Governance and the financial crisis. Int Rev Financ 12(1):7-38

Adams RB, Mehran H (2003) Is corporate governance different for bank holding companies? FRBNY Econ Policy Rev 9(1):123-142

Adams RB, Mehran H (2012) Bank board structure and performance: evidence for large bank holding companies. J Financ Intermed 21(2):243-267

Adams RB, Hermalin BE, Weisbach MS (2010) The role of boards of directors in corporate governance: a conceptual framework and survey. J Econ Lit 48(1):58-107

Admati A, Hellwig M (2013) The bankers' new clothes, what's wrong with banking and what to do about it. Princeton University Press, Princeton

Adolff J, Langenbucher K, Skinner C (2019) State-owned financial institutions. In: Busch D, Ferrarini G, van Solinge G (eds) Governance of financial institutions. Oxford University Press, Oxford, paras 14.01-14.85

Agarwal R, Erel I, Stulz R, Williamson R (2009) Differences in governance practices between US and foreign firms: measurement, causes, and consequences. Rev Financ Stud 22(8):3131-3169

Anginer D, Demirguc-Kunt A, Huizinga H, Ma K (2018) Corporate governance of banks and financial stability. J Financ Econ 130:327-346

Armour J, Gordon JN (2013) Systemic harms and shareholder value. ECGI Law Working Paper No 222/2013, August 2013

Armour J, Awrey D, Davies P, Enriques L, Gordon JN, Mayer C, Payne J (2016) Principles of financial regulation. Oxford University Press, Oxford

Armour J, Gordon JN, Min G (2020) Taking compliance seriously. Yale J Regul 37:1-66

Arner DW, Avgouleas E, Busch D, Schwarcz SL (eds) (2019) Systemic risk in the financial sector. Centre for International Governance Innovation, Waterloo

Aronoff CE, Ward JL (eds) (2011) Family business governance. Palgrave Macmillan, New York

Avgouleas E (2012) Governance of global financial markets, the law, the economics, the politics. Cambridge University Press, Cambridge

Barr MS, Jackson HE, Tahyar ME (2018) Financial regulation: law and policy, 2nd edn. Foundation Press, St. Paul

Barth JR, Levine R (eds) (2016) Regulation and governance of financial institutions. Elgar, Cheltenham

121 See the research agenda presented by Ferrarini (2017). 
Baxter LG (2011) Capture in financial regulation: can we channel it toward the common good? Cornell J Law Public Policy 21:175-200

Bebchuk L, Hirst S (2019) Index funds and the future of corporate governance: theory, evidence and policy. Columbia Law Rev 119:2029-2145

Bebchuk LA, Spamann H (2010) Regulating bankers' pay. Georgetown Law J 98(2):247-287

Becht M (2010) The governance of financial institutions in crisis. In: Grundmann S et al (eds) Festschrift für Hopt (Liber amicorum), vol 2. De Gruyter, Berlin, pp 1615-1627

Becht M, Bolton P, Röell A (2011) Why bank governance is different. Oxf Rev Econ Policy 27(3):437-463

Beltratti A, Stulz RM (2012) The credit crisis around the globe: why did some banks perform better? J Financ Econ 105(1):1-17

Berger AN, Kick T, Schaeck K (2014) Executive board composition and bank risk taking. J Corp Finance 28:48-65

Berger AN, Imbierowicz B, Rauch C (2016) The roles of corporate governance in bank failures during the recent financial crisis. J Money Credit Bank 48:729-770. http://ssrn.com/abstract=2021799. Accessed 30 July 2020

Binder J-H (2015a) The Banking Union and the governance of credit institutions: a legal perspective. EBOR 16:467-490

Binder J-H (2015b) Organisationspflichten und das Finanzdienstleistungs-Unternehmensrecht: Bestandsaufnahme, Probleme, Konsequenzen. Zeitschrift für Unternehmens- und Gesellschaftsrecht (ZGR), pp 667-708

Binder J-H (2016) Anforderungen an die interne Corporate Governance der Institute. In: Grieser SG, Heemann M (eds) Europäisches Bankaufsichtsrecht. Frankfurt School Verlag, Frankfurt, pp $423-461$

Binder J-H (2018) Der Aufsichtsrat von Kreditinstituten-drei Jahre nach dem 'Regulierungstsunami'eine Bestandsaufnahme. Zeitschrift für Unternehmens- und Gesellschaftsrecht (ZGR), pp 88-125

Binder J-H (2019) Corporate governance of financial institutions: in need of cross-sectoral regulation. In: Busch D, Ferrarini G, van Solinge G (eds) Governance of financial institutions. Oxford University Press, Oxford, paras 2.01-2.30

Binder J-H (2020) Der Wirtschaftsprüfer: tragende Säule der Banken-Governance. In: Grundmann S et al (eds) Festschrift für Hopt (Liber amicorum). De Gruyter, Berlin, pp 59-82

Binder J-H, Glos A, Riepe J (eds) (2020) Handbuch Bankenaufsichtsrecht, 2nd edn. RWS Verlag Kommunikationsforum $\mathrm{GmbH}$, Cologne

Boos K-H, Fischer R, Schulte-Mattler H (eds) (2016) KWG CRR-VO, vol I, 5th edn. CH Beck, Munich

Busch D, Palm-Steyerberg I (2019) Fit and proper requirements in EU financial regulation: towards more cross-sectoral harmonization. In: Busch D, Ferrarini G, van Solinge G (eds) Governance of financial institutions. Oxford University Press, Oxford, paras 8.01-8.84

Busch D, Ferrarini G, van Solinge G (eds) (2019a) Governance of financial institutions. Oxford University Press, Oxford

Busch D, Ferrarini G, van Solinge G (2019b) Governing financial institutions: law and regulation, conduct, and culture. In: Busch D, Ferrarini G, van Solinge G (eds) Governance of financial institutions. Oxford University Press, Oxford, paras 1.01-1.35

Carpenter D, Moss DA (eds) (2013) Preventing regulatory capture: special interest influence and how to limit it. Cambridge University Press, Cambridge

Cavaco S, Crifo P, Rebérioux A, Roudant G (2017) Independent directors: less informed but better selected than affiliated board members? J Corp Financ 43:106-121

Cheffins BR (2009) Did corporate governance 'fail' during the 2008 stock market meltdown? The case of the S\&P 500. Bus Lawyer 65:1-65

Chiu IH-Y (ed) (2015) The law on corporate governance in banks. Elgar, Cheltenham

Chiu IH-Y (2016) Regulatory duties for directors in the financial services sector and directors' duties in company law-bifurcation and interfaces. J Bus Law 6:465-490

Coffee JC Jr (2012) The political economy of Dodd-Frank: Why financial reform tends to be frustrated and systemic risk perpetuated. In: Ferran E, Moloney N, Hill JG, Coffee JC (eds) The regulatory aftermath of the global financial crisis. Cambridge University Press, Cambridge, pp 301-371

Cohn A, Fehr E, Maréchal MA (2014) Business culture and dishonesty in the banking industry. Nature 516/4 December 2014, pp 86-89

Corrigan EG (1982) Are banks special? Annual review. The Federal Reserve Bank of Minneapolis 
Davies P, Hopt KJ (2013) Corporate boards in Europe-accountability and convergence. Am J Comp Law 61:301-375

Davies P, Hopt KJ (2019) Non-shareholder voice in bank governance: board composition, performance, and liability. In: Busch D, Ferrarini G, van Solinge G (eds) Governance of financial institutions. Oxford University Press, Oxford, paras 6.01-6.79

Davies P, Hopt KJ, Nowak R, van Solinge G (2013) General report. In: Davies P, Hopt KJ, Nowak R, van Solinge G (eds) Corporate boards in law and practice, a comparative analysis in Europe. Oxford University Press, Oxford, pp 3-115

Davies P, Hopt KJ, Ringe W-G (2017) Control transactions. In: Kraakman R et al (eds) The anatomy of corporate law, 3rd edn. Oxford University Press, Oxford, pp 205-242

de Haan J, Vlahu R (2016) Corporate governance of banks: a survey. J Econ Surv 30(2):228-277

Ellul A, Yerramilli V (2013) Stronger risk controls, lower risk: evidence from U.S. bank holding companies. J Financ 68(5):1757-1803

Emmenegger S (ed) (2014) Bankrecht zwischen Strafrecht und Aufsichtsrecht. Helbing Lichtenhahn, Basel

Emmenegger S (2020a) Grundsätze guter Unternehmensführung von Banken aus der Sicht des Basler Ausschusses. In: Hopt KJ, Binder J-H, Böcking H-J (eds) Handbuch Corporate Governance von Banken und Versicherungen, $\mathrm{CH}$ Beck, Munich, § 4

Emmenegger S (2020b) Corporate Governance von Banken: Fokus USA. In: Grundmann S et al (eds) Festschrift für Hopt (Liber amicorum). De Gruyter, Berlin, pp 189-209

Enriques L, Zetzsche D (2014) Quack corporate governance, round III? Bank board regulation under the new European Capital Requirement Directive. ECGI Law Working Paper No 249/2014, March 2014. Also in: Theoretical Inquiries in Law 16:211-244

Erkens DH, Hung M, Matos P (2012) Corporate governance in the 2007-2008 financial crisis: evidence from financial institutions worldwide. J Corp Financ 38:389-411

ESMT Berlin (2019) Symposium: Debt governance-policy, structuring and stewardship issues. Berlin, 13 November 2019

Fahlenbrach R, Stulz RM (2011) Bank CEO incentives and the credit crisis. J Financ Econ 99:11-26

Fama EF (1985) What's different about banks? J Monet Econ 15(1):29-39

Fernandes C, Farinha J, Martins FV, Mateus C (2018) Bank governance and performance: a survey of literature. J Bank Regul 19:236-256

Ferran E, Moloney N, Hill JG, Coffee JC (eds) (2012) The regulatory aftermath of the global financial crisis. Cambridge University Press, Cambridge

Ferrarini G (2017) Understanding the role of corporate governance in financial institutions: a research agenda. ECGI Law Working Paper No 347/2017, March 2017

Ferrarini G (2019) Compensation in financial institutions: systemic risk, regulation, and proportionality. In: Busch D, Ferrarini G, van Solinge G (eds) Governance of financial institutions. Oxford University Press, Oxford, paras 11.01-11.68

Ferrarini G, Filippelli M (2014) Independent directors and controlling shareholders around the world. ECGI Law Working Paper No 258/2014, May 2014

Ferreira D, Kirchmaier T, Metzer D (2012) Boards of banks. September 2012. http://ssrn.com/abstr act $=1620551$. Accessed 30 July 2020

Ferreira D, Kershaw D, Kirchmaier T, Schuster E-P (2016) Measuring management insulation from shareholder pressure. LSE Legal Studies Working Paper No 1/2016, June 2016. http://ssrn.com/ abstract $=2170392$. Accessed 30 July 2020

Finesi S (2015) suitability of bank directors in Europe: just a matter of being 'fit \& proper'? Eur Co Financ Law Rev (ECFR), pp 45-78

Fleckner AM, Hopt KJ (eds) (2013) Comparative corporate governance, a functional and international analysis. Cambridge University Press, Cambridge

Garnacho Cabanillas L (2019) El gobierno corporativo de las sociedades no cotizadas/Corporate governance of non-listed companies. Revista de Derecho Bancario y Bursátil 154:85-118

Gilson R (2016) From corporate law to corporate governance. ECGI Law Working Paper No 324/2016, September 2016. http://ssrn.com/abstract_id=2819128. Accessed 30 July 2020

Gropp R, Köhler M (2010) Bank owners or bank managers: who is keen on risk? Evidence from the financial crisis. February 2010. http://ssrn.com/abstract=1555663. Accessed 30 July 2020

Hagendorff J (2015) Corporate governance in banking. In: Berger AN, Molyneux P, Wilson JOS (eds) The Oxford handbook of banking, 2nd edn. Oxford University Press, Oxford, pp 139-159 
Hail L, Tahoun A, Wang C (2017) Corporate scandals and regulation. ECGI Law Working Paper No 367/2017, September 2017

Hall PA, Soskice D (eds) (2001) Varieties of capitalism: the institutional foundations of comparative advantage. Oxford University Press, Oxford

Hamdani A (2017) Bank directors: duties towards the public? Society of European Contract Law (SECOLA), 16-17 June 2017. Bocconi University, Milan

Hau H, Thum MP (2010) Subprime crisis and board (in-)competence: private vs. public banks in Germany (21 June 2010). INSEAD Working Paper in Finance No 2010/45/FIN. Econ Policy 24(60):701-752. http://ssrn.com/abstract=1627921. Accessed 30 July 2020

Helleringer G, Skinner C (2019) Conflicts of interest: comparing compliance and culture in the United States and the United Kingdom. In: Busch D, Ferrarini G, van Solinge G (eds) Governance of financial institutions. Oxford University Press, Oxford, paras 20.01-20.80

Hodges CJS (2015) Law and corporate behaviour, integrating theories of regulation, enforcement, compliance and ethics. Hart et al., Oxford et al

Hopt KJ (1998) Self-regulation in banking and finance-practice and theory in Germany. La Déontologie bancaire et financière/The ethical standards in banking and finance. Bruylant, Bruxelles, pp 53-82

Hopt KJ (2011) Comparative corporate governance: the state of the art and international regulation. Am J Comp Law 59:1-73

Hopt KJ (2012) Corporate governance of banks after the financial crisis. In: Wymeersch E, Hopt KJ, Ferrarini $\mathrm{G}$ (eds) Financial regulation and supervision, a post-crisis analysis. Oxford University Press, Oxford, paras 11.01-11.72

Hopt KJ (2013) Corporate governance of banks and other financial institutions after the financial crisis. J Corp Law Stud 13(2):219-253, also in: Miller GP (ed) Economics of financial law, vol II. Elgar, Cheltenham, Part III Governance, 2016, pp 573-607

Hopt KJ (2014) Responsibility of banks and their directors, including liability and enforcement. In: Gorton L, Kleineman J, Wibom H (eds) Functional or dysfunctional-the law as a cure? Risk and liability in the financial markets. Stockholm Centre for Commercial Law, Juridiska fakulteten, Stockholm, pp 159-172

Hopt KJ (2015) Corporate governance in Europe: a critical review of the European Commission's initiatives on corporate law and corporate governance. NY Univ J Law Bus 12:139-213

Hopt KJ (2016) A plea for a bankers' code of conduct. In: Kenadjian PS, Dombret A (eds) Getting the culture and the ethics right, towards a new age of responsibility in banking and finance. de Gruyter, Berlin, pp 75-84

Hopt KJ (2017) Corporate Governance von Finanzinstituten. ZGR 2017:438-459

Hopt KJ (2018) Groups of companies: a comparative study of the economics, law, and regulation of corporate groups. In: Gordon JN, Ringe W-G (eds) The Oxford handbook of corporate law and governance. Oxford University Press, Oxford, pp 603-633

Hopt KJ (2019) Corporate Governance von Banken und Nichtbanken-Ein vergleichender Überblick aus Anlass einer neuen Empfehlung im Deutschen Corporate Governance Kodex 2020. WertpapierMitteilungen. Zeitschrift für Wirtschafts- und Bankrecht (WM) 2019:1771-1779

Hopt KJ (2021) Public Corporate Governance Kodices. In: Dutzi A, Gros M, Nowak K, Roese B (eds) Festschrift für Böcking (Liber amicorum). CH Beck, Munich (forthcoming)

Hopt KJ, Leyens PC (2020) Corporate Governance-Zur nationalen und internationalen Diskussion. In: Hopt KJ, Binder J-H, Böcking H-J (eds) Handbuch Corporate Governance von Banken und Versicherungen, $\mathrm{CH}$ Beck, Munich, $\S 1$

Hopt KJ, Roth M (2015). In: Hirte H, Mülbert PO, Roth M (eds) Aktiengesetz, Großkommentar, 5th edn. de Gruyter, Berlin, Munich, Boston, § 93 AktG Sorgfaltspflicht und Verantwortlichkeit der Vorstandsmitglieder

Hopt KJ, Roth M (2019). In: Hirte H, Mülbert PO, Roth M (eds) Aktiengesetz, Großkommentar, 5th edn. de Gruyter, Berlin, Munich, Boston, §§ 95-116 AktG Aufsichtsrat

Hopt KJ, von Hippel T (eds) (2010) Comparative corporate governance of non-profit organizations. Cambridge University Press, Cambridge

Hopt KJ, von Werder A (eds) (2009) Handbuch corporate governance, Leitung und Überwachung börsennotierter Unternehmen in der Rechts- und Wirtschaftspraxis, 2nd edn. Otto Schmidt, Cologne, Schäffer-Poeschel, Stuttgart

Hopt KJ, Binder J-H, Böcking H-J (eds) (2020) Handbuch Corporate Governance von Banken und Versicherungen, 2nd edn. CH Beck, Munich

Hüffer U, Koch J (2020) Aktiengesetz, 14th edn. CH Beck, Munich 
Jabotinsky H, Siems M (2017) How to regulate the regulators: applying principles of good corporate governance to financial regulatory institutions. ECGI Law Working Paper No 354/2017, May 2017

Johansen K, Laser S, Neuberger D, Andreani E (2017) Inside or outside control of banks? Evidence from the composition of supervisory boards. Eur J Law Econ 43:31-58

Kokkinis A (2018) Corporate law and financial instability. Routledge, London

Kotz H-H, Schmidt RH (2016) Corporate governance of banks-a German alternative to the standard model. Zeitschrift für Bankrecht und Bankwirtschaft (ZBB/JBB), pp 427-444

Kraakman R et al (2017) The anatomy of corporate law, 3rd edn. Oxford University Press, Oxford

Laaper P, Busch D (2019) The Dutch banker's oath and the Dutch Banking Disciplinary Committee. In: Busch D, Ferrarini G, van Solinge G (eds) Governance of financial institutions. Oxford University Press, Oxford, paras 18.01-18.86

Laeven L (2013) Corporate governance: what's special about banks? Annu Rev Financ Econ 5:63-92

Laeven L, Levine R (2009) Bank governance, regulation, and risk taking. J Financ Econ 93:259-275

Langenbucher K (2012) Bausteine eines Bankgesellschaftsrechts, zur Stellung des Aufsichtsrats in Finanzinstituten. Zeitschrift für das gesamte Handelsrecht und Wirtschaftsrecht (ZHR) 176:652-668

Langenbucher K (2020) Anforderungen an den Aufsichtsrat in Banken und Finanzintermediären. In: Hopt KJ, Binder J-H, Böcking H-J (eds) Handbuch Corporate Governance von Banken und Versicherungen. CH Beck, Munich, § 13

Leuz C, Wysocki PD (2016) The economics of disclosure and financial reporting regulation: evidence and suggestions for future research. J Account Res 54(2):525-622

Levine R (2016) The corporate governance of banks: a concise discussion of concepts and evidence. World Bank Policy Research Working Paper No 3404

Leyens PC (2018) Informationsintermediäre des Kapitalmarkts, Private Marktzugangskontrolle durch Abschlussprüfung, Bonitätsrating und Finanzanalyse. Mohr Siebeck, Tübingen

Macey J, O'Hara M (2003) Bank corporate governance: a proposal for the post-crisis world. FRBNY Econ Policy Rev 9(1):91-107

Macey J, O'Hara M (2016) The corporate governance of banks. FRBNY Econ Policy Rev 22:85-105

Mallin CA (ed) (2016) Handbook on corporate governance of financial institutions. Elgar, Cheltenham

Mamatzakis E, Bermpei T (2015) The effect of corporate governance on the performance of US investment banks. Financ Mark Inst Instrum 24(2-3):191-239

Merkt H, Klausmann A (2016) Die europäische und internationale Corporate Governance-Diskussion im Spiegel der ECGI-Research Paper aus der Zeit vom Januar 2012 bis März 2016. Europäisches Wirtschafts \& Steuerrecht (EWS), pp 253-272

Miglionico A (2019) The government of credit rating agencies. Elgar, Cheltenham

Mülbert P, Wilhelm A (2014) Risikomanagement und Compliance im Finanzmarktrecht-Entwicklung der aufsichtsrechtlichen Anforderungen. Zeitschrift für das gesamte Handelsrecht und Wirtschaftsrecht (ZHR) 178:502-546

Mülbert P, Wilhelm A (2015) CRD IV framework for banks' corporate governance. In: Busch D, Ferrarini G (eds) European Banking Union. Oxford University Press, Oxford, paras 6.01-6.85

Mülbert P, Wilhelm A (2020) CRD IV framework for banks' corporate governance. In: Busch D, Ferrarini G (eds) European Banking Union, 2nd edn. Oxford University Press, Oxford, paras 6.01-6.110

Nguyen D, Hagendorff J, Eshraghi A (2016) Can bank boards prevent misconduct? Rev Financ 20(1): $1-36$

Nobel P (2020) Zur Corporate Governance von Banken. In: Grundmann S et al (eds) Festschrift für Hopt (Liber amicorum). De Gruyter, Berlin, pp 881-900

Oulds MK (2017) Anleihebedingungen. In: Hopt KJ, Seibt C (eds) Schuldverschreibungsrecht. Otto Schmidt, Cologne, pp 1174-1216

Paolini A (ed) (2015) Research handbook on directors' duties. Elgar, Cheltenham

Pathan S (2009) Strong boards, CEO Power and bank risk-taking. J Banking Financ 33(7):1340-1350

Pathan S, Faff R (2013) Does board structure in banks really affect their performance? J Bank Financ 37(5):1573-1589

Ringe W-G (2015) Changing law and ownership patterns in Germany: corporate governance and the erosion of Deutschland AG. Am J Comp Law 63(2):493-538

Ringe W-G (2020) Interne und externe Corporate Governance von Banken. In: Grundmann S et al (eds) Festschrift für Hopt (Liber amicorum). De Gruyter, Berlin, pp 1037-1052 
Romano R (2014) For diversity in the international regulation of financial institutions: critiquing and recalibrating the basel architecture. Yale J Regul 31(1):1-76

Saghi-Zedek N, Tarazi A (2015) Excess control rights, financial crisis and bank profitability and risk. J Bank Financ 55:361-379

Saguato P (2019) Financial market infrastructures: the essential role of risk management. In: Busch D, Ferrarini G, van Solinge G (eds) Governance of financial institutions. Oxford University Press, Oxford, paras 10.01-10.59

Schenker U (2017) Corporate Governance in Sanierungsfällen—Der Einfluss der Gläubiger: Chancen und Risiken. In: Weber RH et al (eds) Festschrift von der Crone (Liber amicorum). Schulthess, Zürich, pp 65-89

Schwarcz SL, Jones A, Yan J (2019) Responsibility of directors of financial institutions. In: Busch D, Ferrarini G, van Solinge G (eds) Governance of financial institutions. Oxford University Press, Oxford, paras 7.01-7.56

Siems M, Alvarez-Macotela O (2017) The G20/OECD Principles of corporate governance 2015: a critical assessment of their operation and impact. J Bus Law 4:310-328

Spindler G (2020) Die Neuregelung der Vorstands- und Aufsichtsratsvergütung im ARUG II. Die Aktiengesellschaft (AG) 61-74

Spong K, Sullivan RJ (2010) Bank ownership and risk taking: improving corporate governance in banking after the crisis. September 2010. http://ssrn.com/abstract=1900609. Accessed 30 July 2020

Stulz RM (2016) Risk management, governance, culture, and risk-taking in banks. FRBNY Econ Policy Rev 22(1):43-60

Summers LH (2000) International financial crises: causes, prevention, and cure. Am Econ Rev 90(2):1-16

Tirole J (2001) Corporate governance. Econometrica 69(1):1-35

Tröger T (2017) Managers' duties towards shareholders and debtholders. Society of European Contract Law (SECOLA), 16-17 June 2017, Bocconi University, Milan

Tsagas G (2015) The market for corporate control in the banking industry. In: Chiu IH-Y (ed) The law on corporate governance in banks. Elgar, Cheltenham, pp 285-336

Vallascas F, Mollah S, Keasey K (2017) Does the impact of board independence on large banks risks change after the global financial crisis? J Corp Financ 44:149-166

van den Hurk A, Siri M (2019) Comparative regulation of corporate governance in the insurance sector. In: Busch D, Ferrarini G, van Solinge G (eds) Governance of financial institutions. Oxford University Press, Oxford, paras 3.01-3.71

van der Elst C (2015) Corporate governance and banks: how justified is the match? February 2015. https $: / /$ ssrn.com/abstract $=2562072$. Accessed 30 July 2020

van Setten L (2019) Risk, risk management, and internal controls. In: Busch D, Ferrarini G, van Solinge G (eds) Governance of financial institutions. Oxford University Press, Oxford, paras 9.01-9.62

Wohlmannstetter G (2011) Corporate Governance von Banken. In: Hopt KJ, Wohlmannstetter G (eds) Handbuch Corporate Governance von Banken. CH Beck, Munich, pp 31-73

Wymeersch E, Hopt KJ, Ferrarini G (eds) (2012) Financial regulation and supervision, a post-crisis analysis. Oxford University Press, Oxford

Yasui T (2016) Corporate governance of financial groups. OECD Corporate Governance Working Papers 20/2016

Yeh Y-H, Chung H, Liu C-L (2011) Committee independence and financial institution performance during the 2007-08 credit crunch: evidence from a multi-country study. Corp Gov: Int Rev 19(5):437-458

Zhu S, Ferrarini G (2019) Corporate culture in the governance of financial institutions: an interdisciplinary approach. In: Busch D, Ferrarini G, van Solinge G (eds) Governance of financial institutions. Oxford University Press, Oxford, paras 16.01-16.67

Publisher's Note Springer Nature remains neutral with regard to jurisdictional claims in published maps and institutional affiliations. 